\title{
The Effect of Giving Red-fleshed Watermelon Juice (Citrullus Ianatus (Thunb.)) on Pregnant White Mice (Mus Musculus) Exposed by Monosodium Glutamate (MSG) Orally on the Number and Morphology of Fetus
}

\author{
Dwisari Dillasamola, Fitri Rachmaini*, Dian Ayu Juwita, Rini Haryati
}

Dwisari Dillasamola, Fitri

Rachmaini*, Dian Ayu Juwita, Rini Haryati

Faculty of Pharmacy, Andalas University, INDONESIA.

\section{Correspondence}

Fitri Rachmaini

Faculty of Pharmacy, Andalas University, INDONESIA.

E-mail: fitrirachmaini@phar.unand.ac.id

\section{History \\ - Submission Date: 13-11-2020; \\ - Review completed: 29-11-2020; \\ - Accepted Date: 01-12-2020. \\ DOI : 10.5530/pj.2021.13.14}

Article Available online http://www.phcogj.com/v13/i1

\section{Copyright}

(c) 2021 Phcogj.Com. This is an openaccess article distributed under the terms of the Creative Commons Attribution 4.0 International license.

\begin{abstract}
\section{INTRODUCTION}

Infertility is the failure of a husband and wife to get a pregnancy for at least 12 months of regular sexual intercourse without contraception. ${ }^{1}$ As many as 50 to 80 million couples worldwide experience infertility. ${ }^{2}$ In developing countries, infertility is higher, which is about $30 \%$ compared-fleshed to developed countries $5-8 \%$. The prevalence of infertility in Indonesia varies according to demographic health surveys (the lowest rate is $10 \%$ and the highest is $22 \%$ ) and the number of patients seeking biomedical care. ${ }^{3}$
\end{abstract}

Introduction: Infertility can occur due to the presence of free radicals. One of the most popular of free radical is monosodium glutamate. Free radicals from monosodium glutamate can be prevented by antioxidant compounds. Red-fleshed-fleshed watermelon is a fruit that contains antioxidant compound such as lycopene. Aim: This research was conducted to see the effect of red-fleshed-fleshed watermelon juice on the fetus including number, morphology, visual abnormalities and body weight of pregnant white mice exposed to monosodium glutamate solution orally. Total of 25 female white mice aged around 2-3 months were used as test animals. Methods: Pregnant white mice were divided into 5 test groups. Group I and II served as negative controls (whithout treatment) and positive controls (exposed to monosodium glutamate solution orally at dose of $1 \mathrm{~g} / \mathrm{kgBW}$ ). Group III was given a solution of monosodium glutamate orally at dose of $1 \mathrm{~g} / \mathrm{KgBW}$ added red-fleshed-fleshed watermelon juice at dose of $1.4 \mathrm{~g} / \mathrm{kgBW}$. Group IV was given solution of monosodium glutamate orally at dose of $1 \mathrm{~g} / \mathrm{KgBW}$ added red-fleshed-fleshed watermelon juice at dose of $4.2 \mathrm{~g} / \mathrm{kgBW}$. The research data were processed using the one-way ANNOVA test. Results: The result showed that mice body weight, fetal number and morphology (body weight, body length, tail length, and head diameter) did not significantly influence ( $p>0.05)$. However, it significantly affected the weight gain of mice during pregnancy. However, it significantly affected the weight gain of mice during pregnancy day 6 to day 17 of pregnancy $(p<0.05)$ and found abnormalities in the fetus such as low birth weight (LBW) and haemorrhage in group II and III. Conclusion: It can be concluded that watermelon juice at dose of $2.8 \mathrm{~g} / \mathrm{kgBW}$ and $4.2 \mathrm{~g} / \mathrm{kgBW}$ are effective in ward offfree radicals from monosodium glutamate orally at dose of $1 \mathrm{~g} / \mathrm{kgBW}$.

Key words: Red-fleshed watermelon, Monosodium glutamate, Lycopene, Infertility, Fetus.

The cases of infertility caused by male factors are around $30-40 \%$, the rest is caused by female factors and other unknown factors. Infertility caused by female factors includes ovulation disorders, tubal and pelvic disorders, and uterine disorders. ${ }^{1}$ The disorder is a result of endometriosis. This can lead to fibrosis (hardening of the tissue) which can inhibit the fertilization process by spermatozoa. ${ }^{4}$

One of the causes of infertility is exposure to free radicals. ${ }^{1}$ Free radicals can be defined as atoms or molecules or groups of atoms that have unpaired-fleshed electrons. ${ }^{6}$ Excessive consumption of monosodium glutamate (MSG) can cause the formation of free radicals in the body. MSG consists of sodium salt and L-glutamic acid which are very soluble in water and will dissociate into sodium salt cations and glutamic acid anions. The glutamate in MSG does not bind to protein molecules but in free form so that it can form free radicals. ${ }^{8}$ Excessive consumption of monosodium glutamate in women can cause an imbalance in the levels of the hormones estrogen and progesterone which is play a role in the reproductive cycle. ${ }^{9}$

Normally, the brain is protected by the Blood Brain Barrier (BBB) which functions to prevent excess glutamate in the brain. If there is excess glutamate, it is then pumped back into the glial cells that surround the neurons. When exposed to large amounts of glutamate, these cells will die. Glutamate opens $\mathrm{Ca}^{2+}$ channels in neurons so that $\mathrm{Ca}^{2+}$ enters cells. A number of chemical reactions occur in cells that often trigger the release of chemicals. If the glutamate level, the $\mathrm{Ca}^{2+}$ channel will remain open 
and chemical reactions will also increase which initiates the destruction of cells and cells with glutamate receptors. There are several places in the brain that the Blood Brain Barrier (BBB) cannot protect, including the ventromedial nucleus and nucleus in the hypothalamus. As the center of homeostatic regulation, the hpotalamus plays a role in the secretion of hormones acting on the gonads. Therefore, excessive MSG can cause damage to the arcuatus nucleus and ventromedial nucleus in the hypothalamus causing a decrease in $\mathrm{GnRH}$ secretion which affects the anterior pituitary in secreting gonadotropin hormones, namely Follicle Stimulating Hormone (FSH) and Luteinizing Hormone (LH) to decrease..$^{10}$ Decreased levels of FSH and LH will affect maturation and ovum. ${ }^{11}$

Based on the data obtained, it shows that the average use of Monosodium glutamate in Indonesia is $0.65 \mathrm{gram} / \mathrm{kgBW}$. Meanwhile, the maximum limit for the use of Monosodium glutamate according to the FDA (Food and Drug Administration) and WHO (World Health Organization) is $120 \mathrm{mg} / \mathrm{kg}(50-70 \mathrm{~kg} \mathrm{BW})$. That is, for $50 \mathrm{~kg}$ body weight, the maximum limit for using monosodium glutamate is 6 grams or the equivalent of 1 teaspoon (4-6 grams). ${ }^{12}$ So, the use of monosodium glutamate for the average population of Indonesia is still in a safe range.

In the research that has been done, it was concluded that MSG $0.7 \mathrm{mg} /$ $\mathrm{gBB}$ for 30 days caused a decrease in the number of corpus luteum, an increase in the number of secondary and tertiary follicles, and damage to granulosa cells in mice. This results in implantation failure, endometriosis, and the threat of an ectopic pregnancy which leads to secondary infertility. ${ }^{13}$

Watermelon (Citrullus lanatus) is a plant whose fruit is popular with the people, especially in subtropical areas. This is because watermelon contains more than $90 \%$ water which is suitable for consumption as a thirst quencher. ${ }^{14}$ In addition, watermelon also contains lycopene compounds. Lycopene compounds are compounds from the carotenoid group that act as red-fleshed or yellow coloring in watermelon flesh. Lycopene is also a very powerful antioxidant. ${ }^{15}$ In pregnant women, serum lipid peroxide levels (which produce malondialdehyde (MDA) are higher than nonpregnant women. Malandialdehyde (MDA) is a product produced by lipid peroxidation. Lipid peroxidation occurs due to the presence of free radicals that attack lipids. This is very dangerous for pregnant women because it can cause cell death. The antioxidant function of lycopene can inhibit free radical activity by red-fleshed the occurrence of lipid peroxidation. ${ }^{16,17}$ In fact, in previous studies, no one has examined the relationship between lycopene and inferlity in women. Research that has been done only on the relationship of lycopene to inferlitilas in men, including the benefits of lycopene which can improve the quality of spermatozoa. ${ }^{18-20}$

This study aims to determine the effect of red-fleshed watermelon juice on the number and morphology of the fetus including the number of fetuses, fetal morphology, visual abnormalities of the fetus, and body weight of pregnant white mice exposed to monosodium glutamate orally.

\section{MATERIAL AND METHOD}

\section{Material}

Red-fleshed watermelon (Citrullus lanatus), monosodium glutamate (ajinomoto ${ }^{\circ}$ ), aquades, female white mice (Mus musculus L.).

\section{Preparation of animal experiment}

The test animals used in this study were female white mice of Wistar strain, aged approximately 2 months, body weight ranging from 2030 grams, healthy, had a regular estrous cycle of 4-5 days, placed in maintenance and treatment cage. Acclimatization is carried out for 10 days so that the animals adapt to the experimental environment. ${ }^{21}$
Animals are mated during estrus with ratiof of male to female at 1: 4 . The test animals were mated at four in the afternoon by inserting the male mice into the cage of the female mice and the next morning the vaginal plug was examined. The vaginal plug indicates that the mice are populated and on the 0th day of pregnancy, the mice who have been pregnant are separated and those who are not pregnant are mixed with male mice. $^{22}$

\section{Making test provisions}

Red-fleshed watermelon juice is made in 2 series groups at doses of 1.4 $\mathrm{g} / \mathrm{kg}, 2.8 \mathrm{~g} / \mathrm{kg}$ and $4.2 \mathrm{~g} / \mathrm{kg} .{ }^{15}$ To get red-fleshed watermelon juice with this dose, namely by separating the pulp from the skin and seeds, then the pulp is weighed as much as 100 grams, then blended until smooth. After the watermelon juice is obtained, the watermelon juice is weighed according to the dosage and it is sufficient with distilled water to $10 \mathrm{ml}$

Monosodium glutamate (MSG) solution is prepared-fleshed at a dose of $1 \mathrm{~g} / \mathrm{kgBW}$. To get a solution of monosodium glutamate with this dose, namely by weighing 1 gram of MSG powder, then dissolving it in $10 \mathrm{ml}$ of distilled water

\section{Implementation of Animal Research}

1. Mice were acclimatized for 10 days before being tested.

2. Mice are mated

3. Mice are given a test preparation for 10 days

4. On the 18th day of pregnancy, a laparotomy is performed

5. Observed

\section{Data Analysis}

Observation Parameters :

1. Mice body weight during pregnancy day 6 to day 17 of gestation.

2. Number of fetuses.

3. Fetal morphology (body weight, body length, head circumference, tail length).

4. Visual fetal abnormalities (site resorption, spontaneous abortion, slow growth, low birth weight, haemorrhage).

\section{RESULTS AND DISCUSSION}

This study aims to determine the effect of giving red-fleshed watermelon juice to pregnant white mice exposed to monosodium glutamate orally on the number and morphology of the fetus. Watermelon is used because this fruit is a source of natural antioxidants such as beta carotene, vitamin C, citrulline, B vitamins especially B1 and B6, lycopene cucurbitasin, triterpenes, sterols and alkaloids as well as minerals such as potassium and magnesium..$^{15,23,24}$ In group II, oral administration of monosodium glutamate at dose of $1 \mathrm{~g} / \mathrm{kgBW}$ did not significantly affect body weight of the mice, number and fetal morphology (body weight, body length, tail length, and head diameter) ( $p>0.05)$. However, the fetus has abnormalities in the form of haemorrhage (all fetuses) and 1 head had low birth weight (LBW).

In group III, oral administration of monosodium glutamate at a dose of $1 \mathrm{~g} / \mathrm{kg}$ plus red-fleshed watermelon juice at a dose of $1.4 \mathrm{~g} / \mathrm{kgBW}$ did not significantly affect the body weight of the mice, the number and morphology of the fetus (body weight, body length, tail length, and head diameter) ( $p>0.05)$. However, the fetus has abnormalities in the form of haemorrhage (1 fetus) and low birth weight (LBW) (1 fetus).

In group IV, oral administration of monosodium glutamate at a dose of $1 \mathrm{~g} / \mathrm{kg}$ plus red-fleshed watermelon juice at a dose of $2.8 \mathrm{~g} / \mathrm{kgBW}$ 
did not significantly affect the body weight of the mice, the number and morphology of the fetus (body weight, body length, tail length, and head diameter) ( $\mathrm{p}>0.05)$ and also there were no abnormalities.

In group $\mathrm{V}$, the oral administration of monosodium glutamate at a dose of $1 \mathrm{~g} / \mathrm{kg}$ plus red-fleshed watermelon juice at a dose of $4.2 \mathrm{~g} / \mathrm{kgBW}$ did not significantly affect the body weight of the mice, the number and morphology of the fetus (body weight, body length, tail length, and head diameter) $(\mathrm{p}>0.05)$ and there were no abnormalities in the fetus.

Based on the results of observations that have been carried out, it shows that the administration of red-fleshed watermelon juice to pregnant white mice exposed to monosodium glutamate orally in groups II, III, IV, and V did not affect the number of fetuses, body weight of pregnant white mice, and fetal morphology in the form of body weight.
, head diameter, body length and tail length were significantly ( $\mathrm{p}>$ 0.05 ) as shown in Figures 1-6. However, administration of red-fleshed watermelon juice to pregnant white mice exposed to monosodium glutamate affected the weight gain of pregnant white mice during pregnancy day 6 to day 17 of gestation significantly $(p<0.05)$ as shown in Figure 7. and in groups II and III cause abnormalities in the fetus such as haemorrhage as shown in Figure 8. and low birth weight (LBW) as shown in Figure 9.

Spontaneous haemorrhage can be caused by platelet dysfunction. Haemorrhage is the discharge of blood from the cardiovascular system accompanied by accumulation in body tissues. Haemorrhage shock occurs mostly during pregnancy. Haemorrhage shock can be seen with changes in body temperature. The condition of failure to regulate body temperature or also known as hyperthermia is caused by the inability
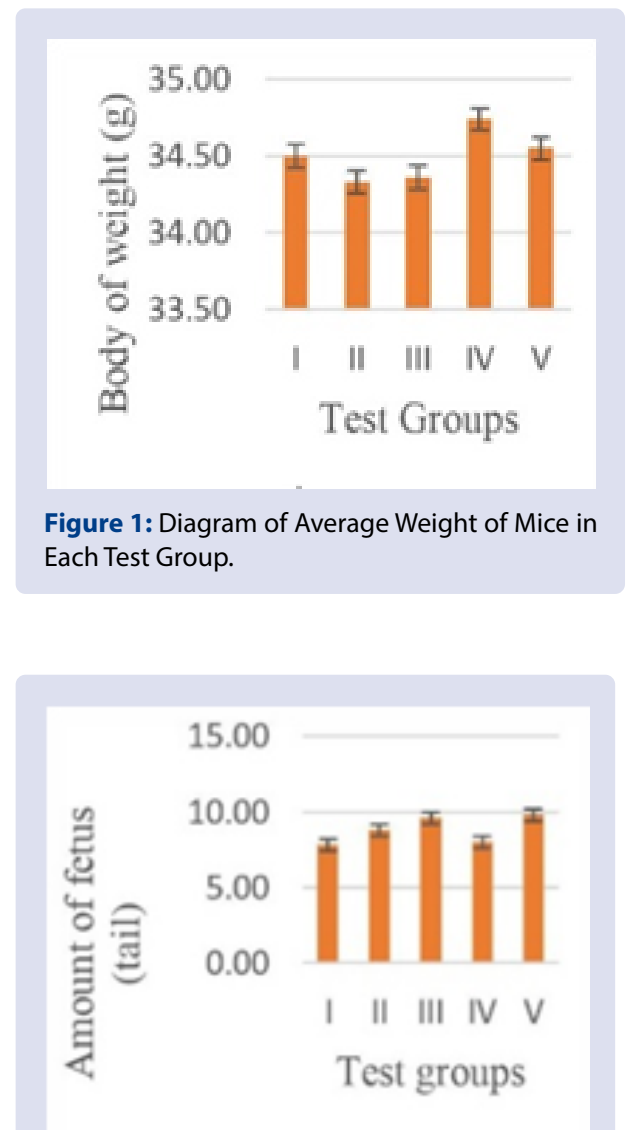

Figure 2: Diagram of Average Number of Fetuses in Each Test Group.

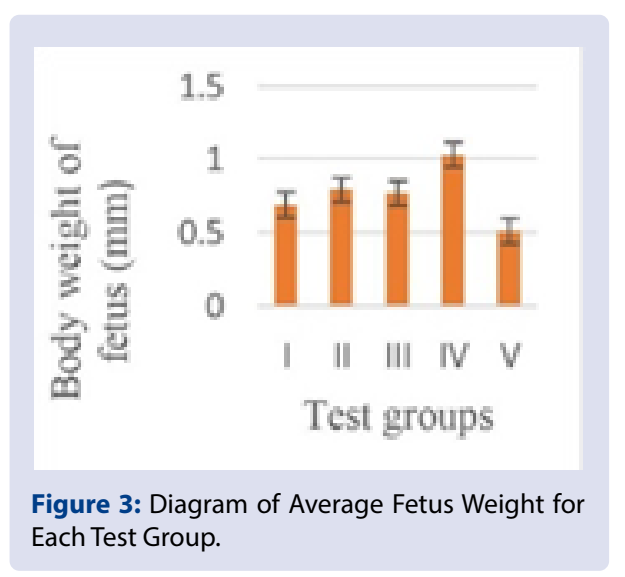

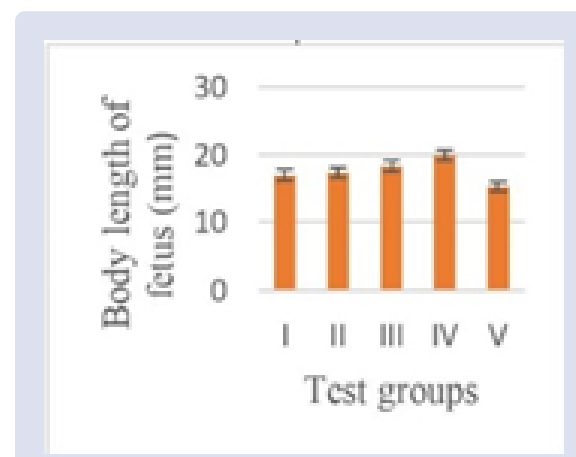

Figure 4: Diagram of Average Fetal Body Length for Each Test Group.
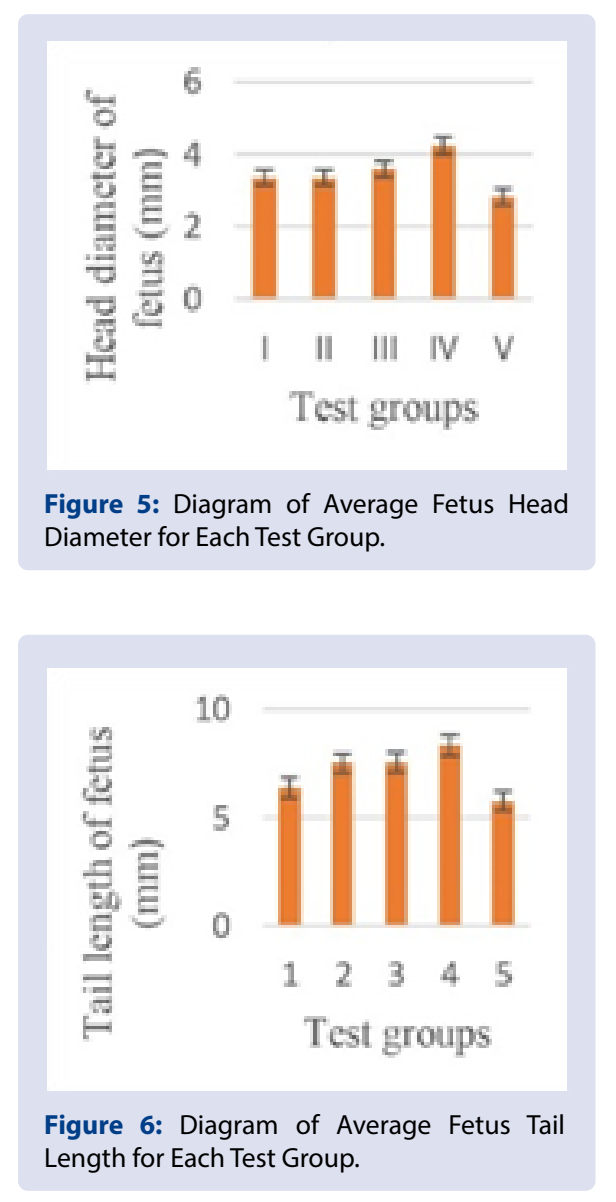


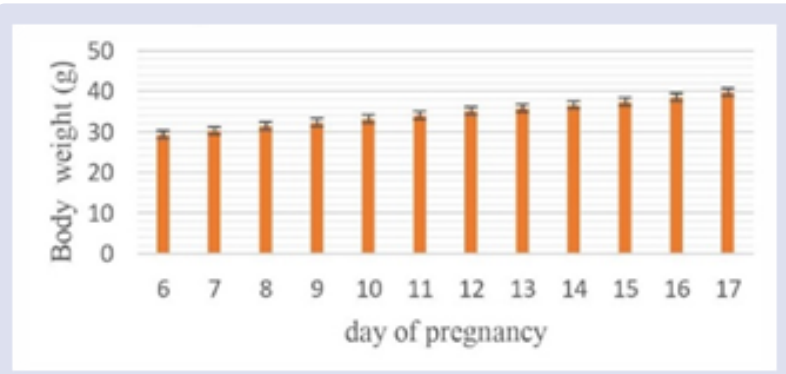

Figure 7: Diagram of the average weight gain of pregnant white mice during pregnancy day 6 to day 17.

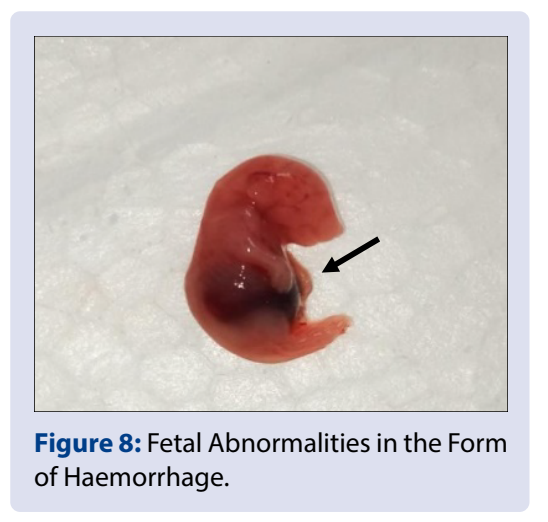

of the body to release or release excessive heat by the body with heat dissipation at a normal rate. It is possibly this hyperthermia that can cause haemorrhage. Monosodium glutamate which is consumed in excessive amounts will cause glutamate in the body to increase which causes cell metabolism to increase so that it stimulates the body to produce a reactive product called Reactive Oxygen Species (ROS). If the increase in ROS is not balanced with antioxidants, it can cause oxidative stress. This oxidative stress can cause damage to the hypothalamus. The hypothalamus plays a role in body temperature regulation, so that if there is damage to the hypothalamus it will interfere with the regulation and control of body temperature and later can result in hyperthermia and haemorrhage. ${ }^{10,11,25,26}$

From the results of these studies it can be concluded that consumption of monosodium glutamate without being balanced with antioxidants can cause several abnormalities in the fetus, so if pregnant women consume it, it is advisable to balance the effects of free radicals with antioxidant compounds such as watermelon.

\section{CONCLUSION}

From the research that has been done, it is concluded that giving red-fleshed watermelon juice to pregnant white mice exposed to monosodium glutamate does not affect the number of fetuses, body weight of pregnant white mice, and fetal morphology in the form of weight, head diameter, body length and tail length significantly, but affect fetal weight gain of pregnant white mice during pregnancy day 6 to day 17 and there are abnormalities in the fetus such as haemorrhage and low birth weight (LBW).

\section{ACKNOWLEDGEMENTS}

The authors would like to deliver a special appreciation to the Dean of Faculty of Pharmacy of Universitas Andalas for the financial support based on the Research Grant of faculty of Pharmacy Universitas Andalas.

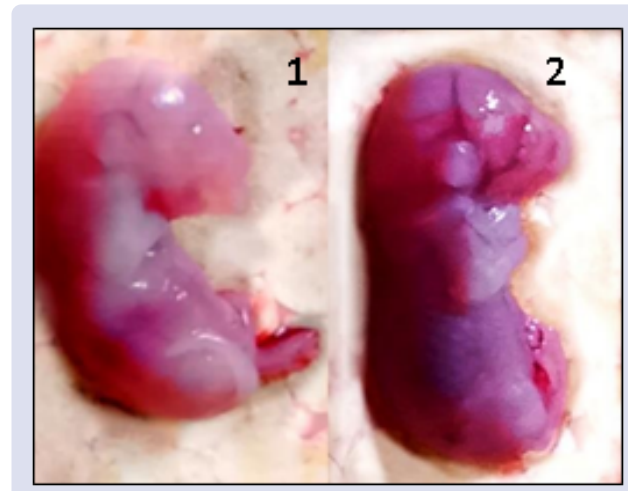

Figure 9: (1) Abnormal Low Birth Weight (LBW) (2) Normal.

\section{Table 1: Experimental animal grouping.}

\begin{tabular}{|c|c|}
\hline Group & Treatment \\
\hline I & Negative control (given only eat and drink) \\
\hline II & $\begin{array}{l}\text { Positive control (given monosodium glutamate orally dose } 1 \mathrm{~g} / \\
\text { kgBW) }\end{array}$ \\
\hline III & $\begin{array}{l}\text { Given oral monosodium glutamate at a dose of } 1 \mathrm{~g} / \mathrm{kgBW} \text {, red- } \\
\text { fleshed watermelon juice is added with dose of } 1.4 \mathrm{~g} / \mathrm{kgBW}\end{array}$ \\
\hline IV & $\begin{array}{l}\text { Given oral monosodium glutamate at a dose of } 1 \mathrm{~g} / \mathrm{kgBW} \text {, red- } \\
\text { fleshed watermelon juice is added with dose of } 2.8 \mathrm{~g} / \mathrm{kgBW}\end{array}$ \\
\hline $\mathrm{V}$ & $\begin{array}{l}\text { Given oral monosodium glutamate at a dose of } 1 \mathrm{~g} / \mathrm{kgBW} \text {, red- } \\
\text { fleshed watermelon juice is added with dose of } 4.2 \mathrm{~g} / \mathrm{kgBW}\end{array}$ \\
\hline
\end{tabular}

\section{CONFLICTS OF INTEREST}

The author(s) declare(s) that there is no conflict of interest regarding the publication of this article.

\section{REFERENCES}

1. PERFITRI H. Penanganan Konsensus Infertilitas. Hesdiantoro A, editor. 2013

2. World Health Organization. Global Prevalence of Infrtility, Infecundity and Childlessness [Internet]. 2012. Available from: https://www.who.int/ reproductive health/topics/infertility/burden/en/

3. Bennett. Indonesian Infertility Patients'Health Seeking Behaviour and Patterns of Access to Biomedical Infertility Care: an interviewer administered-fleshed survey conducted in three clinics. 2012 Available from: http://www.reproductivehealth- journal.com/content/9/1/24

4. Astarto NW. Pengaruh Likopen Terhadap Kualitas dan kadar Malondialdehid Spermatozoa yang Dipajankan pada Zalir Peritoneum Wanita dengan Endometriosis. 2014;4.

5. Easley IV CA, Simerly CR, Schatten G. Stem cell therapeutic possibilities: Future therapeutic options for male-factor and female-factor infertility? Reproductive Biomedical Online. 2013;27(1):75-80.

6. Suryohudoyo P. Oksidan, Antioksidan dan Radikal Bebas. Laboratorium Biokimia Fakultas Kedokt Unair. 1993.

7. Kabel AM. Free Radicals and Antioxidants: Role of Enzymes and Nutrition World J Nutr Heal. 2014;2(3):35-8.

8. Kaseke MM. Gambaran histologik ginjal tikus Wistar yang diberikan jus tomat setelah diinduksi dengan monosodium glutamat Kandidat Skripsi Fakultas Kedokteran Universitas Sam Ratulangi Monosodium glutamat ( MSG ) sering masakan di kehidupan sehari hari . Monosodium g. 2016;4:4-7.

9. Umami R, Made Dwijayasa P, Winarsih S. Pengaruh Vitamin C dan E terhadap Histologi Tuba Fallopii pada Tikus yang Dipapar MSG. Jurnal Kedokteran Brawijaya. 2014;28(2):63-7.

10. Giovambattista A, Suescun MO, Nessralla CCDL, França LR, Spinedi E, Calandra RS. Modulatory effects of leptin on leydig cell function of normaland hyperleptinemic rats. Neuroendocrinology. 2003;78(5):270-9.

11. Putranto KA. Pengaruh Pemberian Monosodium Glutamate (MSG) Terhadap Gambaran Histologis Testis Mencit. digilib UNS. 2011;2:5-16.

12. Eka Widyalita P, Saifuddin Sirajuddin Z. Analysis of Monosodium Glutamate (MSG) in Street Food at SD Lariangbangi Complex in Makassar. JK Unila. 2014;2:2. 
Dillasamola, et al.: The Effect of Giving Red-fleshed Watermelon Juice (Citrullus lanatus (Thunb.)) on Pregnant White Mice (Mus Musculus) Exposed by Monosodium Glutamate (MSG) Orally on the Number and Morphology of Fetus

13. Megawati D. Siklus Estrus dan Struktur Hi stologis Ovarium Tikus Putih ( Rattus norvegicus L.) Setelah Pemberian Monosodium Glutamat (MSG) Secara Oral. 2005.

14. Sunyoto, Sudarso D, Budiyanti T. Petunjuk Teknis Budidaya Semangka. 2006. 1-35 p.

15. Monica E, Rollando R. Identifikasi Dan Isolasi Senyawa Likopen Dari Semangka (Citrullus Lanatus). 2019;16(1):80-5.

16. Prasetyastuti, Sunarti. Vitamin E Dan Malondialdehid Darah Wanita Hamil Di Daerah Endemik Gondok Di Jawa Tengah. Berita Kedokteran Masyarakat. 2008;24(2):65-8

17. Sulistyowati Y. Pengaruh Pemberian Likopen Terhadap Status Antioksidan (Vitamin C, Vitamin E Dan Gluthathion Peroksidase) Tikus (Rattus norvegicus galur Sprague Dawley) Hiperkolesterolemik. Univ Stuttgart. 2006;

18. Ningrum, M.S D. Pengaruh Semangka(Citrullus vulgaris Schrad.) Terhadap Kualitas Spermatozoa Mencit (Mus musculus L.) Dipaparkan Asap Rokok. 2016;

19. Alfa N, Mustofa S, Irawati NAV. Likopen, Antioksidan Eksogen yang Bermanfaat bagi Fertilitas Laki-laki. Majority. 2019;
20. Durairajanayagam D, Agarwal A, Ong C, Prashast P. Lycopene and male infertility. Asian Journal of Andrology. 2014.

21. Dillasamola D, Helmi A, Dhila SM. The effect of ethanol extract of Beetroot (L.) on the number, morphology spermatozoa and testis weigh in Male Mice (Mus Musculus) by exposure to heat. Der PharmaChem. 2016;8(19):608-14.

22. A A. Teratologi Eksperimental. padang: Andalas University Press; 2012

23. Erhirhie E, Ekene N. Medicinal Values on Citrullus lanatus (Watermelon) Pharmacological Review. International Journal and Research Pharmceutiical and Biomedical Science. 2014;4(4):1305-12.

24. Perkins-Veazie P, Collins JK, Pair SD, Roberts W. Lycopene content differs among red-fleshed-fleshed watermelon cultivars. Journal of Sciences and Food Agriculture. $2001 ; 81(10): 983-7$.

25. Meydani SN. ImmunologicEffect of Yogurt. 2017;(January).

26. Sari NP. Pengaruh Pemberian Propolis terhadap Skeletal Fetus Mencit (Mus musculus) yang Diinduksi Kafein. 2017.

\section{GRAPHICAL ABSTRACT}

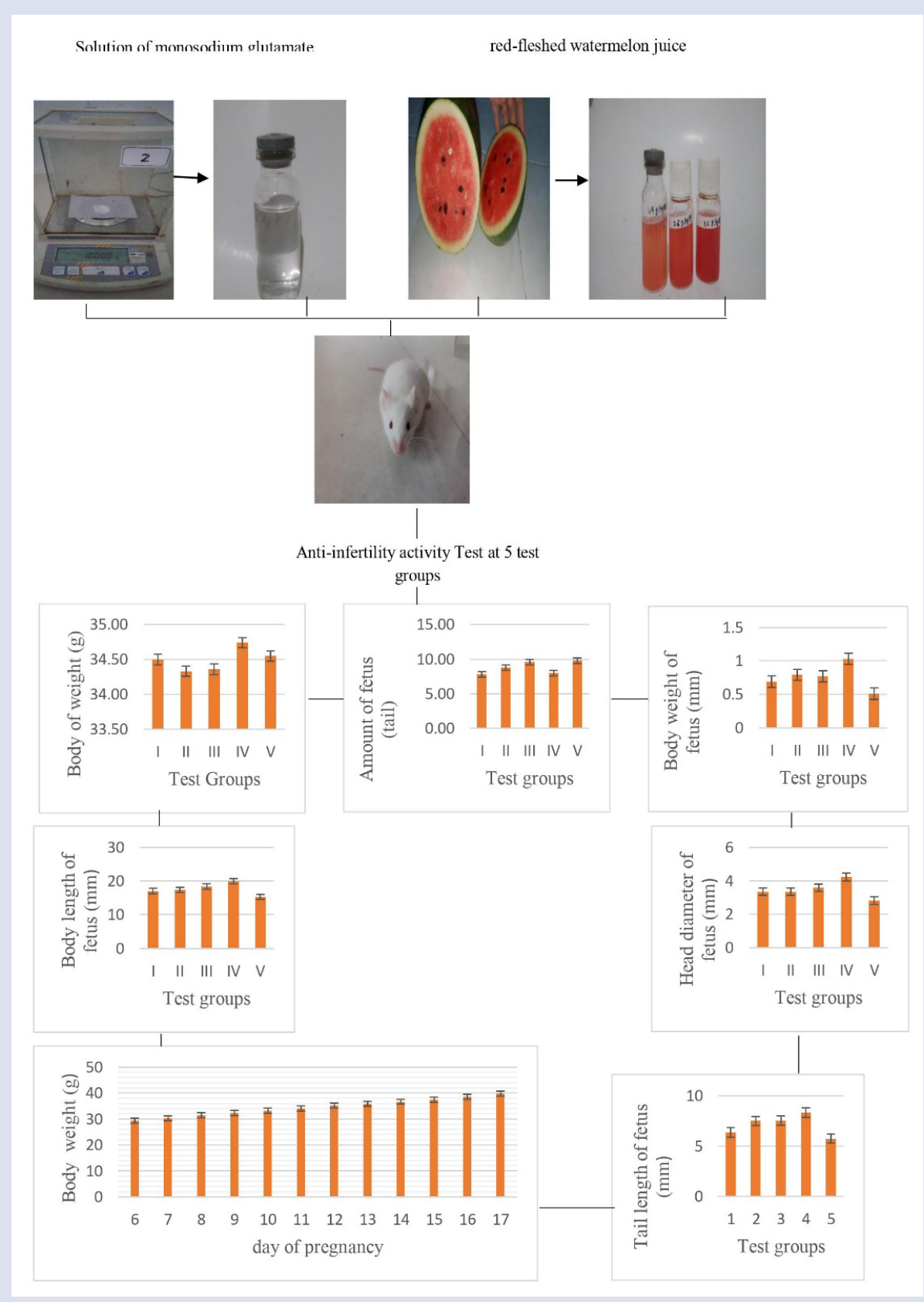


Dillasamola, et al.: The Effect of Giving Red-fleshed Watermelon Juice (Citrullus lanatus (Thunb.)) on Pregnant White Mice (Mus Musculus) Exposed by Monosodium Glutamate (MSG) Orally on the Number and Morphology of Fetus

\section{SUMMARY}

Red-fleshed watermelon is a fruit that contains antioxidant compound such as lycopene. This research was conducted to see the effect of red-fleshed watermelon juice on the fetus including amount, morphology, visual abnormalities and body weight of pregnant white mice exposed to monosodium glutamate solution orally. Group I and II served as negative controls (whithout treatment) and positive controls (exposed to monosodium glutamate solution orally at dose of $1 \mathrm{~g} / \mathrm{kgBW}$ ). Group III was given a solution of monosodium glutamate orally at dose of $1 \mathrm{~g} / \mathrm{KgBW}$ added red-fleshed watermelon juice with dose 1.4 $\mathrm{g} / \mathrm{kgBW}$. Group IV was given a solution of monosodium glutamate orally at a dose of $1 \mathrm{~g} / \mathrm{KgBW}$ added red-fleshed watermelon juice at dose $4.2 \mathrm{~g} / \mathrm{kgBW}$. The research data were processed using the one-way ANNOVA test. The result showed that mice body weight, fetal number and morphology (body weight, body length, tail length, and head diameter) did not significantly influence $(p>0.05)$. However, it significantly affected the weight gain of mice during pregnancy. However, it significantly affected the weight gain of mice during pregnancy day 6 to day 17 of pregnancy $(p<0.05)$ and found abnormalities in the fetus such as low birth weight (LBW) and haemorrhage in group II and III. It can be concluded that watermelon juice at dose of $2.8 \mathrm{~g} / \mathrm{kgBW}$ and $4.2 \mathrm{~g} / \mathrm{kgBW}$ are effective in ward offfree radicals from monosodium glutamate orally at dose of $1 \mathrm{~g} / \mathrm{kgBW}$.

\section{ABOUT AUTHORS}

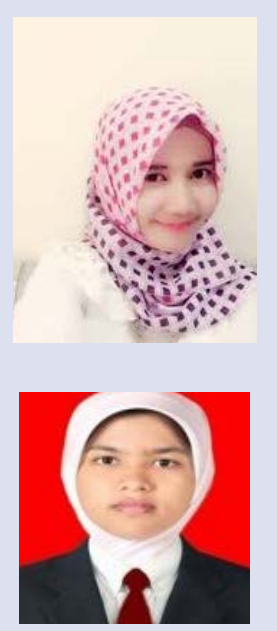

Dwisari Dillasamola, M.Farm, Apt.: Currently as a lecturer in a functional position at the Faculty of Pharmacy, Andalas University. Graduated from the Faculty of Pharmacy, Andalas University in 2004, then the Masters Program at Faculty of Pharmacy, Andalas University in 2011. Her research and expertise are in the field of Pharmacology-toxicology. Currently working as a lecturer in Pharmacology and Clinical Pharmacy at the Faculty of Pharmacy, Andalas University.

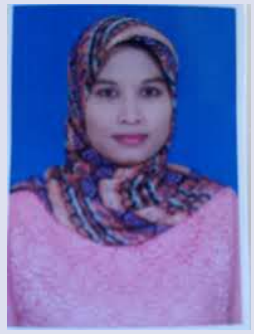

Fitri Rachmaini, M. Si, Apt.: Currently a lecturer at the Faculty of Pharmacy, Andalas University. Graduated from the Faculty of Pharmacy, Andalas University in 2015, then the Masters Program in 2018 at the Bandung Institute of Technology, School of Pharmacy. Currently working as a lecturer in Pharmacology and Clinical Pharmacy at the Faculty of Pharmacy, Andalas University.

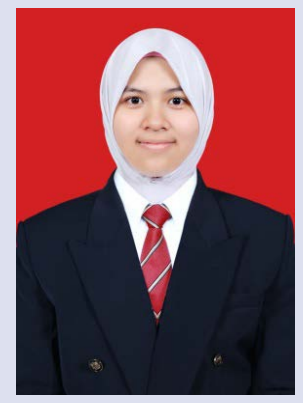

Rini Haryati : She is a student at Faculty of Pharmacy, Andalas University who has been involved in research that studies The Effect of Giving Red-fleshed Watermelon Juice (Citrullus Lanatus (Thunb.)) on Pregnant White Mice (Mus Musculus) Exposed By Per Oral Monosodium Glutamate (MSG) on The Morphology and Amount of Fetus

Cite this article: Dillasamola D, Rachmaini F, Juwita DA, Haryati R. The Effect of Giving Red-fleshed Watermelon Juice (Citrullus lanatus (Thunb.)) on Pregnant White Mice (Mus Musculus) Exposed by Monosodium Glutamate (MSG) Orally on the Number and Morphology of Fetus. Pharmacog J. 2021;13(1): 97-102. 